\title{
The Cytogenetic Effects of Logran on Human Lymphocyte Culture
}

\author{
Fulya Dilek Gokalp Muranlı* and Fisun Kaymak \\ Department of Biology, Faculty of Arts and Sciences, Trakya University, 22030 Edirne, Turkey
}

Received August 31, 2004; accepted October 30, 2004

\begin{abstract}
Summary In this study, the cytogenetic effects of a sulphonylurea group herbicide Logran (effective substance; Triasulfuron) were investigated in human peripheral blood lymphocyte culture. The cultures were treated with $2,4,8,16,32,64,128$, and $256 \mu \mathrm{g} / \mathrm{ml}$ concentrations of Logran for 24 and $48 \mathrm{~h}$. This compound increased chromosome aberrations (CA) in human lymphocyte culture. Logran decreased Mitotic Index (MI) related to the concentrations. Between the concentrations of 16 and $256 \mu \mathrm{g} / \mathrm{ml}$ Logran, this herbicide is cytotoxic and clastogenic in human peripheral blood lymphocyte culture treated in vitro.
\end{abstract}

Key words Logran, Herbicide, Chromosome aberrations, in vitro lymphocyte culture.

Nowadays humans are exposed to the effects of various chemical substances due to developing industry and technology.

These chemical substances can be agricultural pests, food additives and medicines. These compounds may have significant effects for many generations. Therefore, it is important to determine the mutagenic effects of these compounds by the appropriate test systems.

Suphonylurea herbicides are used to control broad-leaved weeds. Logran is one of the sulphonylurea herbicides and its active substance is triasulfuron. This herbicide is used extensively, especially on wheat grown agricultural area in Turkish Trakya. It is known that about 10-12000 kg Logran is used on a 2-2.3 million hectare agricultural land in a single season in Edirne province. Excessive use of these sulphonylurea herbicides in agricultural areas may accumulate in soil and water. Thus, they may reach to the organisms and may result in several harms. Althought the effects of some urea group herbicides are investigated (Agrawal et al. 1996, Chauhan et al. 1998, Papapaulou et al. 2001) there is no report about cytogenetic effects of Logran on animals and humans.

Testing agents for their ability to induce CA has a firm place in screening strategies for mutagenic/carcinogenic agents (Ishidate et al. 1998, Kirkland 1998, Obe et al. 1982). Detailed cytogenetic assay dealing with chromosome aberration is one of the important ways for evaluating genotoxic agents in vivo and in vitro (Carrano and Natarajan 1988, Natarajan and Obe 2002). CAs are induced by agents that damage chromosomal DNA (Natarajan 1976, Roberts 1978, Singer and Grunberger 1983). Therefore, scoring chromosomal aberrations is a direct measure of chromosome breakage and offers an accurate evaluation of the clastogenic (chromosome breakage) activity of an agent.

In the present study it was aimed to investigate the cytogenetics effects and dose response relations of Logran (commercial formulation of Triasulfuron) in human blood lymphocyte culture.

Material and method

In the present study, human peripheral blood was used as material, and Logran as a test substance. Logran consists of $4 \%$ triasulfuron $\left(\mathrm{C}_{14} \mathrm{H}_{16} \mathrm{ClN}_{5} \mathrm{O}_{5} \mathrm{~S}-3\right.$ - $(6$-methoxy-4-methyl-1,3,5-triazine-

* Corresponding author, e-mail: fulyad1@yahoo.com 
2-yl)-1-(2-(2-chloroethoxy)-phenylsuftonyl)urea), and 60\% terbutyn $\left(\mathrm{C}_{10} \mathrm{H}_{19} \mathrm{~N}_{5} \mathrm{~S} 2\right.$ tert. butylamino4-ethylamino-6-methylthio-s-triazine).

Concentrations of Logran were prepared by dissolving in distilled water. Two healthy and nonsmoking females who were 23 and 26 years old were chosen as donors. $0.5 \mathrm{ml}$ of blood taken from a donor was added to a $5 \mathrm{ml}$ culture medium. Culture medium includes $10 \%$ Fetal Calf Serum (Sigma), 2\% Phytoheamagglutinin (Sigma, CAS No. 9008-97-3), $100 \mathrm{IU} / \mathrm{ml}$ penicillin, $100 \mu \mathrm{g} / \mathrm{ml}$ Streptomycin and Ham's F-10 (Sigma). These culture bottles were incubated for $72 \mathrm{~h}$ at $37^{\circ} \mathrm{C}$. The cultures were treated with the final concentrations of $2,4,8,16,32,64,128$, and $256 \mu \mathrm{g} / \mathrm{ml}$ of Logran for 24 and $48 \mathrm{~h}$. As for control group (negative control) the culture was not treated with the chemical substance but it was treated with distilled water. At $3 \mathrm{~h}$ prior to harvesting, $0.6 \mu \mathrm{g} / \mathrm{ml}$ colchicine was added to arrest the cells at metaphase. After incubation, the cells were collected by centrifugation for $10 \mathrm{~min}$ at $1000 \mathrm{rpm}$. Then resuspended in a pre-warmed hypotonic solution $(0.075 \mathrm{M} \mathrm{KCl})$ for $25 \mathrm{~min}$ and fixed in glacial acetic acid: methanol $(1: 3 \mathrm{v} / \mathrm{v})$. This fixation step was repeated until the lymphocytes' color were turned to white. Preparations were air dried and slides were stained with $10 \%$ Giemsa in Sörensen buffer for $10 \mathrm{~min}$.

100 metaphases were scored for each concentration and treatment period and aberrations were recorded; chromatid gap, chromatid break, isochromatid gap, isochromatid break were determined. MI was determined by counting 2000 lymphocytes ( $\mathrm{MI}$ was calculated as $\mathrm{MI}=\mathrm{M} / \mathrm{T}$, where $\mathrm{M}$ represents the number of methaphase cells, $\mathrm{T}$ is the total number of cells scored).

In the present study, the results were tested with the Fishers' Exact $\chi_{2}$ test both including (gap + ) and excluding (gap -) gaps; the significance of the results of each treatment group was determined by comparing them with the control group.

\section{Results}

2, 4, $8 \mu \mathrm{g} / \mathrm{ml}$ of Logran concentrations did not induce significant CAs excluding gaps (gap -) for both donors. If we accept gaps as CA (gap +$) 8 \mu \mathrm{g} / \mathrm{ml}$ concentration of Logran significantly induced abnormalities for 24 and $48 \mathrm{~h}$ treatment period in donor A and for $48 \mathrm{~h}$ treatment period in donor B. It was not needed to show the results of low concentrations of Logran $(2,4,8 \mu \mathrm{g} / \mathrm{ml})$ in a table because of little changes in CAs.

Table 1 shows types and frequencies of structural chromosomal aberrations of higher concentration of Logran $(16,32,64,128$ and $256 \mu \mathrm{g} / \mathrm{ml})$. According to the data a clear cut direct cytotoxic effect of Logran was seen in human lymphocytes. Logran decreased MI with the increasing concentrations. The highest concentration $(256 \mu \mathrm{g} / \mathrm{ml})$ of Logran diminished mitosis in both donors except $24 \mathrm{~h}$ treatment in donor A. $128 \mu \mathrm{g} / \mathrm{ml}$ concentration for $48 \mathrm{~h}$ treatment period also diminished mitosis in donor A, decreased MI to $0.5 \%$ in donor B. In donor A, after $24 \mathrm{~h}$ treatment period, 16,32 and $256 \mu \mathrm{g} / \mathrm{ml}$ concentrations of Logran, and after $48 \mathrm{~h}$ treatment period $16 \mu \mathrm{g} / \mathrm{ml}$ concentration of Logran induced statistically significant CA (gap -).

In donor B after $24 \mathrm{~h}$ treatment period $32,128 \mu \mathrm{g} / \mathrm{ml}$ concentrations of Logran, and after $48 \mathrm{~h}$ treatment periods 64 and $128 \mu \mathrm{g} / \mathrm{ml}$ concentrations of Logran induced statistically significat CA (gap -).

The herbicide Logran damaged the chromosome structure at concentrations between 16 and $256 \mu \mathrm{g} / \mathrm{ml}$, but no correlation was found between the concentrations and frequency of chromosome aberrations. This herbicide also induced CA for both 24 and $48 \mathrm{~h}$ treatment periods. Only in one donor (B) at $48 \mathrm{~h}$ treatment, more abnormal cells were observed compared to $24 \mathrm{~h}$ treatment period. 128 and $256 \mu \mathrm{g} / \mathrm{ml}$ Logran concentrations after 24 and $48 \mathrm{~h}$ treatment period, diminished the amount of mitosis and brought about chromosomal changes difficult to estimate quantitatively. Therefore these concentrations could not be scored for CA induction shown as ( - ) in Table 1.

Our results show a dose dependent increase of abnormal cell number at all concentrations for 


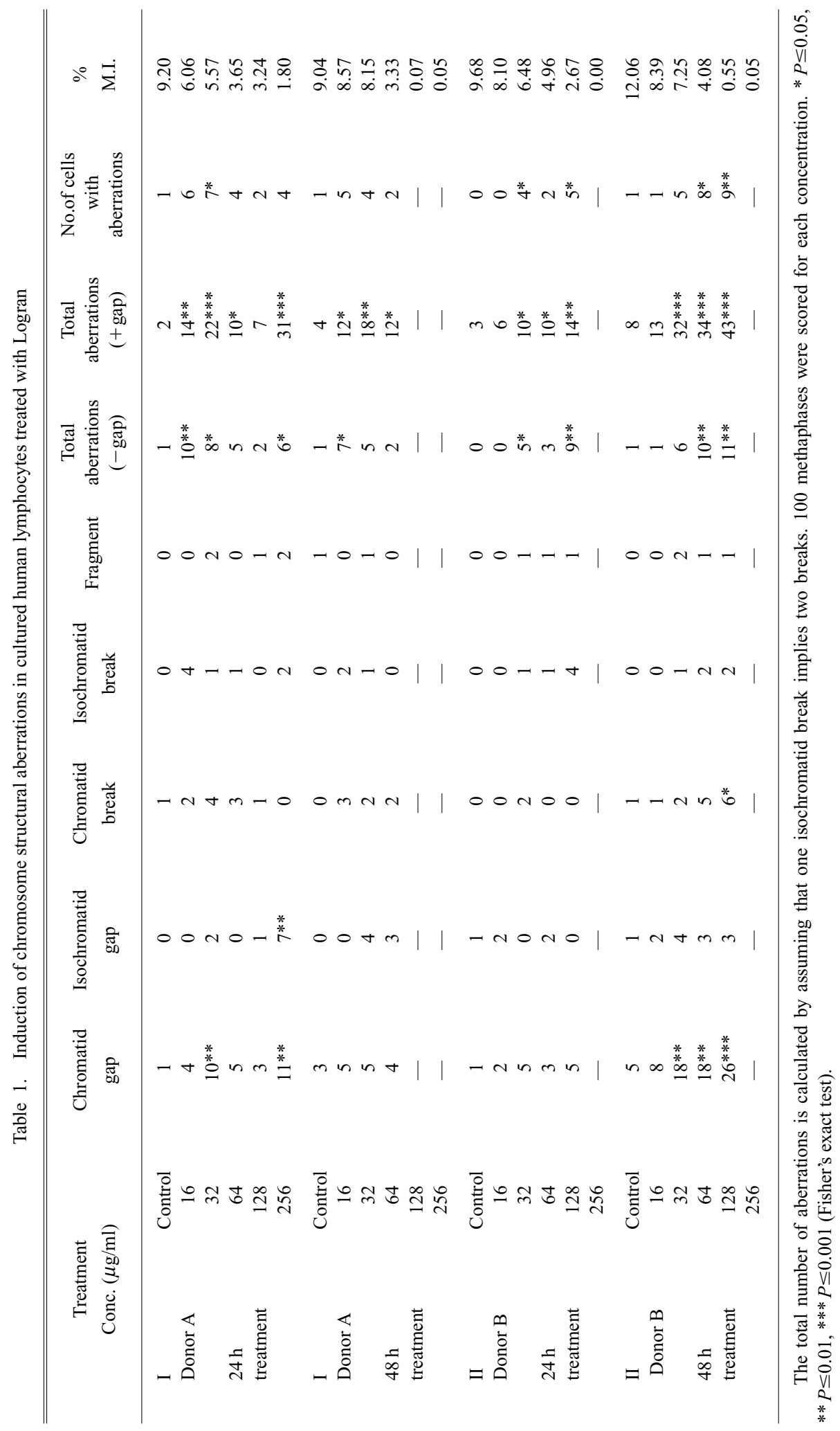



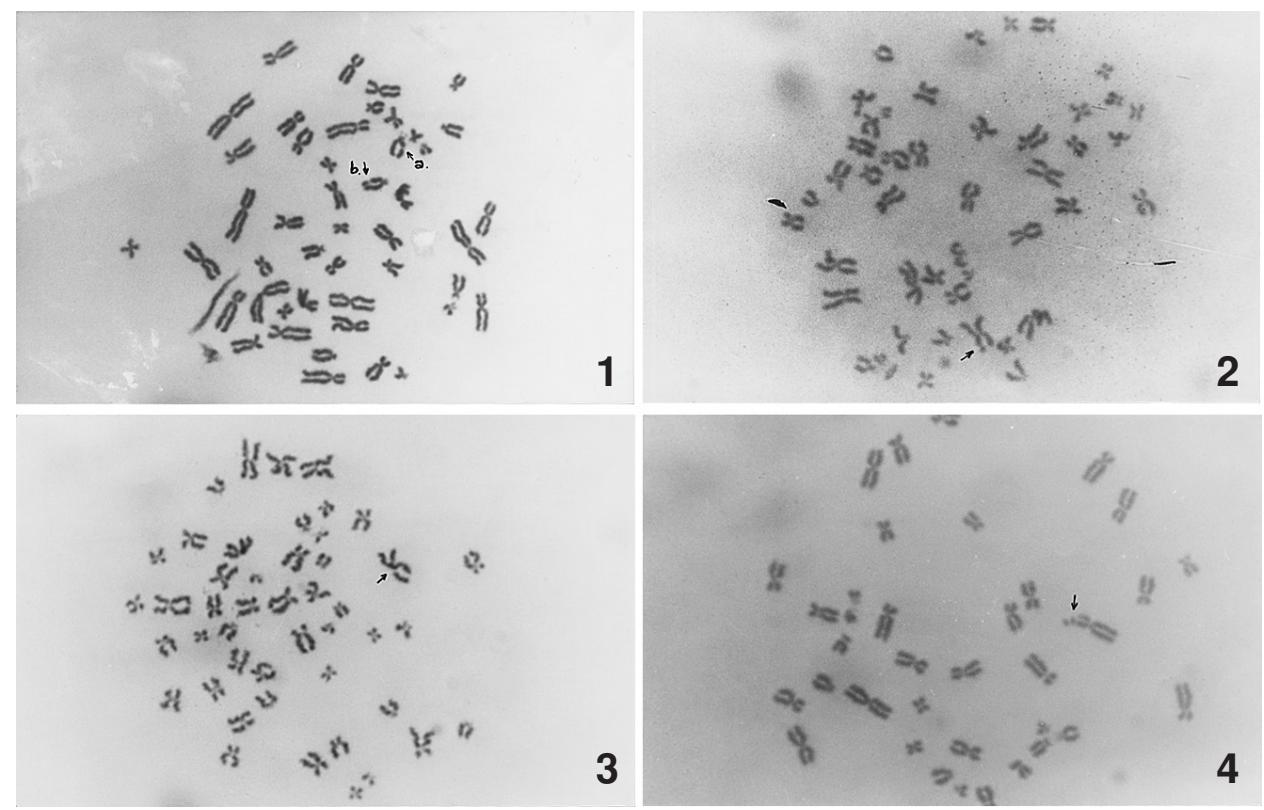

Fig. 1-4. 1. Observed aberrations after $128 \mu \mathrm{g} / \mathrm{ml}$ Logran treatment for $48 \mathrm{~h}$. a. Chromatid gap, b. Chromatid break $(\times 1000)$. 2. Chromatid break observed after $64 \mu \mathrm{g} / \mathrm{ml}$ Logran treatment for $48 \mathrm{~h}$ $(\times 1000)$. 3. Chromatid break observed after $64 \mu \mathrm{g} / \mathrm{ml}$ Logran treatment for $24 \mathrm{~h}(\times 1000)$. 4. Isochromatid break observed after $256 \mu \mathrm{g} / \mathrm{ml}$ Logran treatment for $24 \mathrm{~h}(\times 1000)$.

two donors $($ gap +$)$.

Some examples of CA are shown in Figs. 1-4.

\section{Discussion}

Chromosome aberration cytogenetic assay is one of the biological end points for evaluating genotoxic agents in vivo and in vitro (Carrano and Natarajan 1988, Natarajan and Obe 1982).

It has been shown by many investigators that pesticides induce CA in human lymphocytes (Cid and Matos 1987, Grant and Salamone 1994, Hrelia et al. 1996, Sinha et al. 1995). No such research exists about the effects of Logran and its compound Triasulfuron on hereditary material. However, in studies of Ciba-Giegy it is reported that this chemical regressed body development being toxic on liver and induced systemic toxicity in mice, rats, rabbits and dogs (Cid and Matos 1987, CibaGeigy 1985, 1986a, 1986d, 1988).

In the present study Logran induced CAs at concentrations between 16 and $256 \mu \mathrm{g} / \mathrm{ml}$ in cultured human lymphocytes. Papapaulou et al. (2001) reported that Linuron (urea compund herbicide) induced micronuclei (MN) frequency and this induction resulted from breakage events as well as chromosome loss. Therefore, it is stated that Linuron is clastogenic in human lymphocytes. In the study of Agrawal et al. (1996) one of the urea herbicide Diuron induced the formation of MN and it was clastogenic in bone marrow cells of Swiss mice. Chlorpropamide (sulfonylurea drug) used as hypoglycemic agent significantly induced CA and chromosome exchange aberrations in lymphocytes of diabetic patients (Scasselati-Sforzolini et al. 1997). Although it has found that Chlorpropamide has not significantly induced chromatid aberrations and chromosome exchanges in chromosomal aberration test in Chinese hamster and mice (Renner and Münzner 1980), an increased number of sister chromatid exchanges (SCE) are found by investigations in vitro on Chinese hamster V79 cells treated with Chlorpropamide (Brown and Wu 1977). Watson et al. (1976) 
reported that chlorpropamide acts on DNA molecule indirectly. Since it binds strongly to serum protein, it may produce its effects indirectly by affecting enzyme function.

In the present study Logran induced CA in cultured human lymphocytes without metabolic activation, although no correlation was found between the increase in frequency of aberrations and the herbicide concentration. Sheldon (1989) also found similar result with caprolactam without metabolic activation in human lymphocytes (Sheldon 1989). In the study of Walter et al. (1980) no correlation was found between the Malathion (insecticide) concentrations and frequency of CA (Walter et al. 1980).

Mitotic index (MI) data is an acceptable measure of cytotoxicity for lymphocyte cultures (Galloway et al. 1994, OECD 1997). In the present study Logran reduced mitotic activity of cells. Logran decreased MI with the increasing concentrations. For a variety of chemicals concentrations which give 50-70\% supression of MI can be exctremely toxic concentrations (Armstrong et al. 1992). In the present study the concentration reduced MI of $50 \%$ up to $70 \%$ is $64 \mu \mathrm{g} / \mathrm{ml}$. Lower concentrations (16 and $32 \mu \mathrm{g} / \mathrm{ml}$ ) also reduced MI and induced CA. At all the concentrations it was seen a dose response reduction of mitotic activity. Logran is cytotoxic in human lymphocytes. It has been reported that many of the herbicides and insecticides inhibit mitotic activity (Lioi et al. 1998, Oraler et al. 1984, Surrales et al. 1995, Topaktas and Rencüzogulları 1994). Walter et al. (1980) indicated that Malathion (insecticide) is cytotoxic in human lymphocytes. Five pyretroid insecticides, cypermethrin, deltamethrin, fenpropathrin, fenvalarate and permethrin, induced clear dose dependent cytotoxic effects (Surrales et al. 1995). Urea compound herbicide Linuron is cytotoxic in human lymphocytes (Agrawal et al. 1996) and in rat hepatic, bone marrow and testes cells (Scasselati-Sforzolini et al. 1997). Aldicarb is toxic in cultured human lymphocytes (Cid and Matos 1987).

In the present study the highest concentration $(256 \mu \mathrm{g} / \mathrm{ml})$ of Logran diminished mitosis for both donors except $24 \mathrm{~h}$ treatment in donor A. $128 \mu \mathrm{g} / \mathrm{ml}$ concentration for $48 \mathrm{~h}$ treatment also diminished mitosis in one donor and decreased MI to $0.05 \%$ in donor B. Walter et al. (1980) have found similar results with the insecticide Malathion with the concentrations 50 and $70 \mu \mathrm{g} / \mathrm{ml}$ for the same treatment periods in cultured human lymphocytes. Studies on the effects of cyneb and cyram on the mitotic activity of cultured cells revealed that higher concentrations of these pesticides diminish MI (Szichowa et al. 1977).

In conclusion, Logran induced significant CA in human lymphocyte culture althought in the present test conditions no correlation was found between concentration and frequency of aberrations excluding gaps (gap -). Logran decreased MI related to the concentrations. Logran is cytotoxic and clastogenic in human lymphocyte culture without metabolic activation between the concentrations 16 and $256 \mu \mathrm{g} / \mathrm{ml}$ in the laboratory conditions. Therefore, further cytogenetic studies dealing with clastogenicity and genotoxicity of Logran may reveal more interesting results.

\section{References}

Armstrong, M. J., Bean, C. L. and Galloway, S. M. 1992. A quantitative assessment of the cytotoxicity associated with chromosomal aberration detection in Chinese hamster ovary cells. Mutat. Res. 265: 45-60.

Agrawal, R. C., Kumar, S. and Mehrotra, N. K. 1996. Micronucleus induction by diuron in mouse bone marrow. Toxicology Letters 89: 1-4.

Brown, R. F. and Wu, Y. 1977. Induction of sister chromatid exchanges in Chinese hamster cells by chlorpropamide. Mutat. Res. 56: 215-217.

Carrano, A. V. and Natarajan, A. T. 1988. Consideration for population monitoring using cytogenetic techniques. Mutat. Res. 204: 379-406.

Chauhan, L. K. S., Saxena, P. N., Sundararaman, V. and Gupta, S. K. 1998. Diuron induced cytological and ultrastructural aberrations in the root meristem cells of Allium cepa. Pesticide Biochemistry and Physiology 62: 162-163.

Cid, M. G. and Matos, E. 1987. Chromosomal aberrations in cultured human lymphocytes treated with aldicarb, a carbamate pesticide. Mutat. Res. 191: 99-103.

Ciba-Geigy Corporation 1985. MRID No. 40271947. EPA Washington, DC 20460. 
- 1986a. MRID No. 40271965, 4052401, 40887601. EPA Washington, DC 20460.

- 1986d. MRID No. 40271949. EPA Washington, DC 20460.

— 1988. MRID No. 40728316. EPA Washington, DC 20460.

Galloway, S. M., Aardema, M. J., Ishidate, Jr. M., Ivett, J. L., Kirkland, D. J., Morita, T., Mosesso, P. and Sofuni, T. 1994. Report fron working group on in vitro tests for chromosome aberrations. Mutat. Res. 312: 241-261.

Grant, W. F. and Salamone, M. F. 1994. Comporative mutagenicity of chemical selected for test in the International Programe on Chemical Safety's collaborative study on plant systems for the detection of environmental mutagens. Mutat. Res. 310: 187-209.

Hrelia, P., Maffei, F., Fimognari, C., Vigagni, F. and Cantelli-Forti, G. 1996. Cytogenetic effects of Metalaxyl on human and animal chromosomes. Mutat. Res. 369: 81-86.

Ishidate, M., Miura, K. F. and Sofuni, T. 1998. Chromosome aberration assays in genetic toxicology testing in vitro. Mutat. Res. 404: 167-172.

Kirkland, D. 1998. Chromosome aberration testing in genetic toxicology-past, present and future. Mutat. Res. 404: 173-185.

Lioi, M. B., Scarfi, M. R. and Santoro, A. 1998. Cytogenetic damage and induction of pro-oxidant state in human lymphocytes exposed in vitro to gliphosate, vinclozoline, atrazine and DPX-E 9636. Environ. Mol. Mutagen 32: 39-45.

Natarajan, A. T. 1976. Molecular aspects of the origin of chromosome structural changes. Biol. Zbl. 95: 139-156.

— and Obe, G. 1982. Mutagenicity: New Horizons in Genetic Toxicology. Academic Press. ISBN 0-12-336180-X. pp. $172-184$.

Obe, G., Pfeiffer, P., Savage, J. R. K., Johannes, C., Goedeche, W., Jeppesen, P., Natarajan, A. T., Martinez-Lopez, W., Folle, G. A. and Drets, M. E. 2002. Chromosomal aberrations: formation, identification and distribution. Mutat. Res. 504: $17-36$.

OECD, TG 473 1997. B.10.Mutagenicity_In Vitro Mammalian Chromosome Aberration test. Organisation for Economic Cooperation and Development, Paris, 1997.

Oraler, G., Gozukırmızı, N. and Olgun, A. 1984. Bazı pestisitlerin fraklı organizmalardaki mutagenik etkileri. Doğa Bilim Dergisi, A2 8: 105-114.

Papapaulou, P., Vlastos, D., Stephanou, G. and Demopoulos N. A. 2001. Linuron cytogenetic activity on human lymphocytes treated in vitro. Evaluation of clastogenic and aneugenic potential using cytokinesis block micronucleus assay in combination with fluorescence in situ hybridization (FISH). Fresenius Environmental Bulletin 10: 431-437.

Renner, H. W. and Munzner, R. 1980. Mutagenicity of sulphonylureas. Mutat. Res. 77: 349-355.

Roberts, J. J. 1978. The repair of DNA modified by cytotoxic, mutagenic, and carcinogenic chemicals, in J. J. Lett, H. Adler (Eds), Advances in Radiation Biology, Academic Press, New York. pp. 211-442.

Sarmah, A. K., Kokana, R. S. and Alston, A. M. 1998. Fate and behaviour of triasulfuron, methsulfuron-methyl, and chlorsulfuron in the Australian soil environment. A review. Aust. J. Agric. Res. 49: 775-790.

- , - and - 1999. The degredation of Chlorsulfuron and riasulfuron was investigated in alkaline soils under laboratory conditions. Weed Res. 39: 83-94.

Scasselati-Sforzolini, G., Pasquini, R., Moretti, M., Villarini, M., Fatigoni, C., Dolara, P., Monarca, S., Caderni, G., Kuchenmeister, F., Schmezer, P. and Pool-Zobel, B. L. 1997. In vivo studies on genotoxicity of pure and commercial Linuron. Mutat. Res. 390: 207-221.

Scott, D., Galloway, S. M., Marshall, R. R., Ischidate, Jr. M., Brusick, P., Ashby, J. and Myhr, B. C. 1991. Genotoxicity under extreme culture conditions. A report from ICPEMC Task Group 9. Mutat. Res. 257: 147-204.

—, Danford, N. D., Dean, B. J.and Kirkland, D. J. 1990. Metaphase chromosome aberration assays in vitro, in: D. J. Kirkland (Ed), Basic Mutagenicity Tests; UKEMS Recommended Procedures. Cambridge University Press, Cambridge. pp. 62-86.

Sheldon, T. 1989. Chromosomal damage induced by caprolactam in human lymphocytes. Mutat. Res. 224: 325-327.

Singer, B. and Grunberger, D. 1983. Molecular Biology of Mutagens and Carcinogens, Plenum Press, New York.

Sinha, S., Panneerselvam, N. and Shanmugam, G. 1995. Genotoxicity of the herbicide butachlor in cultured human lymphocytes. Mutat. Res. 344: 63-67.

Surrales, J., Xamena, N. and Creus, A. 1995. The suitability of the micronucleus assay in human lymphocytes as a new biomaker of excision repair. Mutat. Res. 342: 43-59.

Szichowa, A. P., Elizarowa, O. N., Zidkowa, L. W., Koczjetkowa, T. A., Lewin, A. J., Rjazanowa, R. A. and Szjewyrjewa, N. A. 1977. Izuczjenije djejstwija pesticidow na mitoticzeskuju aktiwnost kljetok stabilnycl linij. In: Metody gigjeniczeskoji toksykologiczeskoj ocenki biologiczjewskovo diejstwija pesticydow. pp. 159-161. Moscow: Izd. Medicina.

Topaktas, M. and Rencüzogullarü, E. 1994. Kültıre edilmis, insan periferal lenfositlerinde Carbosulfan'ın C-Mitotik etkisi. 12. Ulusal Biyoloji Kongresi 6-8 Temmuz Molekuler Biyoloji, Genetik ve Mikrobiyoloji Seksiyonu Cilt 5, 217-223. 
Walter, Z., Czajkowska, A. and Lipeeka, K. 1980. Effect of Malathion on the genetic material of human lymphocytes stimulated by phytohemagglutinin (PHA). Human Genetics 375-381.

Watson, W. A. F., Petrie, J. C., Galloway, D. B., Bullock, I. and Gilbert, J. C. 1976. In vivo cytogenetic activity of sulphonylurea drugs in man. Mutat. Res. 38: 71-80. 